\title{
ETHNO BOTANICAL PLANTS AND THEIR UTILIZATION SURVEY AGAINST COVID-19 AT RURAL NEWASA AREA OF AHMEDNAGAR DISTRICT (M.S.)
}

\author{
B.N. Sonawane ${ }^{1 *}$, C.S. Arsule ${ }^{2}$ and S.R. Kale ${ }^{1}$ \\ 1. Shri Dnyaneshwar Mahavidyalaya Newasa, Dist. Ahmednagar (M.S.) \\ 2. New Arts, Commerce and Science College Ahmednagar (M.S.) \\ E.mail- *sbn3310@gmail.com \\ csarsule@gmail.com
}

\begin{abstract}
:
The human infected cases of COVID-19 (Corona virus disease) are still increasing day-by-day all over the world. It is infectious disease caused by a newly discovered corona virus. COVID-19 is a large family of viruses that causes illness ranging from the common cold to more severe acute respiratory syndrome. Common symptoms of infection include respiratory are fewer, cough, shortness of breath and breathing problem. In some cases infection causes pneumonia, kidney failure, heart attack and even death. Recommendations to avoid infection spread include covering mouth and nose with mask, sanities or wash hand regularly, thoroughly cooking fresh vegetable, use fresh fruit and also cooking meat and egg.

In present research survey standard recommendation that use ethno botanical plants to prevent and control corona virus disease. Total 21 plants showed to increase immunomodulatory activity, antiviral activity and inhibitory potential growth of corona virus disease. This may be due to the routine use of immunomodulatory medicinal plants, out of these most common plants used as Tinospora cordifolia, Agele marmelos, Curcuma longa, Ocimum sanctum, Withania somnifera, Adathoda vasica, Zingiber officinal, Emblica officinallis, Aloe vera, Azedercta indica, Citrus limon, Cocculus hirstus, Cymbopogon citrates, Allium cepa, Hyptis suaveolens, Boerhavia diffusa, Phyllanthus nuri, Eclipta alba, Carica, Papaya, Citrus sinensis and Citrus limetta. It is there by suggested that ethno botanical plants must be investigated on a priority basis to solve the current crisis COVID-19 issue.
\end{abstract}

Keywords: COVID-19, Ethno botanical plants, preventive measures.

\section{INTRODUCTION:}

There are many ethno botanical plants indigenous to India and used in the Indian systems of Medicine which have been reported as potent antiviral with immune modulatory and anti-asthmatic activities. Corona virus disease 2019 (COVID-19) is a life-threatening global health scenario. The WHO (World Health Organization) has announced this disease as global issue. The severity of this disease causes highest death rate from December 2019 October 2020 worldwide. There is an urgent need to develop medicines and vaccine to prevent the immune system of human. Medicinal plants and based drugs play a major role in preventing by provoking the immune system. The use of herbal plants to withstand human health is a biggest challenge according to doctors in Ayurveda, siddha to find medicinal plants which are of with many complex molecules those are not easy to derive. The medicinal drug can be derived from turmeric, ginger, cinnamon, cloves, tulsi, fenugreek and fennel seeds. These are important man-found medicines to cure many complicated health ailments. With the aid of scientist and 
researcher there is an urgency to find the natural ways to cure this disease and to make strong anti-COVID-19 herbal medicines from endless plants suffering from illness through the COVID-19. A.vasica has been used in the Indian medicinal system for thousands of years to treat various types of respiratory disorders (Sampath Kumar et al., 2010). A. sativum also shows antiviral effect against avian influenza virus $\mathrm{H}_{9} \mathrm{~N}_{2}$ on Vera cells (Rasool et al., 2017). Additionally, curcumin the main constituent in Circuma longa L. (Zingiberaeae), is suggested as a potential clinical option for the treatment of SARS-CoV-2 infection, due to its action in several steps of a viral infection such as protease inhibition, cellular signaling pathways modulation, among others (Zahedipourer al., 2020), 11 medicinal plants were discussed concerning their in vitro antiviral activity using different models. Two species (Allium sativum $L$. and Zingiberr Officinal Roscoe) mentioned in this study that had their invitro potential and immune capacity assessed, were also include in our study. C. longa extract at also showed antiviral potential against dengue virus in in vitro and in vitro studies on Huh7it - 1 cell and a remarkable reduction in viral loads has been observed by in invivo model (Ichsyani et al., 2017). Hydro - alcoholic extract of Ocimum sanctum in habited intracellular multiplication of virus. It also inhabits non-specific interference with virus- cell interactions in H9N2 viruses. (Ghoke et al., 2018). In vitro screening of $T$. cordifolia silver nanoparticles against chikunguniya virus cell showed significant antiviral potential (Sharma V. et al., 2018. Another study on with none showed blockage of SARS - CoV -2 entry and also its subsequent infection by interrupting electrostatic interactions between the RBD and ACE2 (Balkrishn et al., 2020). The hydro alcoholic extract of $\mathrm{T}$. cordifilica stem in drinking water caused enhancement of cellular immunity as well as humeral immunity in broiler chocks (Netyet. Al., 2017). Ginger showed antiviral potential against avian influenza virus H9N2 on Vero ells in a dose dependent its manner (Rasool et. al., 2017). Curcuma longa virtual screening of (Curcuming and its anaogae found its activity SARS COV 2 surface protein and is under clinical trial (Kim et al., 2009) Alcoholic extract of bael stimulate immune system by acting through cellular and humeral immunity (Ptel and Asdag 2020). An isolated compound $(1,2,3,6$-tetra-galloyl- $\beta$ - $d$ glucose) of $P$. emblica showed antiviral potential against HSV by HSV -inactivation of virus, suppression of intracellular growth and inhibited gene expression of HSV-1E and L along with DNA replication (Xiang et al., 2011). The bitter taste of neem helps in clearing the mucous of fungi while having common cold by the way of steaming and taken as preventive medicine for COVID- 19. Bhimangouda S Patil, G.K.J., Kotambali n Chidambara Murthy 2017 and Francesco Meneguzzo, R.C., Federica Zabini, Mario Pagliaro., 2020. Based on our current knowledge of this virus and in the absence of a vaccine, this article is an attempt to propose ways to prevent treat and control the COVID-19 virus, using medicinal plants such as Eucalyptus globules Labill, Cymbopogon citratus, Mentha, citrus, Zingiber officinale, Syzygium aromaticum which have been showen to be effective. Indications in the context of respiratory conditions. Cymbopogen citratus is indicated for respiratory infection (CUBA, 2014). For an herbal medicine to be a medicine high quality chemically well- characterized and pharmacologically well- studies preparations are acceptable only. Equally, it will be essential thet such well- characterized preparations are used in all future pharmacological and clinical studies (Hrinrich et al., 2020). Overall, we 
heighted the potential of some medicinal plants for the adjuvant management of early symptoms of flu within the context of COVID19 in otherwise healthy adults. The juice or tea of Citrus limon (L.) Burm. F fruits, alone or associated with salt, honey or ginger has been used to relive cough and fever related to flu and cold in several traditional system (KlimekSzczykutowicz et al., 2020). However, there is no clinical evidence of such action in the respiratory tract, although this species is wellknown as a rich source of vitamin C (Ye 2017). The administration of Phyllanthus niruri $\mathrm{L}$ extract can increase the activity and function of several components of the nonspecific immune system and specific immune system, both dissolved (humorous) and cell- related forms. This study aims to determine Phyllanthus niruri L as an immunomodulator for Covid-19. Carica papaya leaves, which are proposed to be a herbal treatment for SARS- coronavirus-2.

\section{MATERIAL AND METHODS:}

The present investigation is based on survey study of ethno botanical plants in different villages of Newasa taluka district Ahmednagar located between $19.5512^{\circ}$ North latitudes and $74.9281^{\circ}$ East longitudes on world map during 2019-2020. The ethno botanical plants were collected form fields and brought to the laboratory. The plants were identified with the help of Marathwada - V.N. Naik (1998). The ethno botanical value of plants was verified with the knowledge of elder people, aged rural folks traditional ayurvedic practitioners, local herbal drug sellers, through interview, discussion, viva and referring literature of Naik (19998), Trivedi (2003-2008), Mali and Bhadane (2011), Mohammad NafeesIqbal and Surdakar (2011), Lal and Singh (2012), Bhogaonkar and Ahmad (2012), Nag and Hasan (2013), Muley and Sharma (2013), Biradar (2013)

\section{RESULT AND DISCUSSION: ETHNO BOTANICAL PLANTS AND ITS APPLICATION AGAINST COVID -19}

\section{CONCLUSION:}

Many plants possess beneficial antiviral compounds now it is used regularly by people to treat COVID-19 disease. The proper utilization of traditional medicines against COVID-19 Pandemic disease would help people in many ways to safe guard and elevate the immune system. Our work suggested that Tinospora cordifolia, Agle maramelos, Curcuma longa, Ocimum sanctum, Withania somnifera, Adthoda vasica, Zingiber officinale, Emblica officinalis, Aloe vera, Azedercta indica, Citrus limon, Cocculus hirstus, Cymbopogon citrates, Allium sativum, Hyptis suaveolens, Boerhavia diffusa, Phyllanthus nuri, Eclipa alba, Carica papaya, Citrus sinensis, Citrus limetta, have safety margins superior to those of reference drugs and enough levels of evidence to merit their potential clinical use as adjutants in the treatment of early/ mild cases of COVID-19.

The SARS-CoV-2 has become a threat to human population due to non-availability of approved of vaccines or drugs for its treatment. Many plants that have been reported to work as an immunity booster against COVID-19. Indian Traditional Medicines have a wide potential for being used in these tough times either for prophylaxis or as adjuvant, owing to their longstanding use in community, ancient references and scientific evidence about their safety and clinical efficacy.

\section{REFERENCES:}

Balkrishna, A., Pokhrel, S., Sing, J., and Varshney, A. (2000). With none form Withania somnifera may inhibit novel corona virus (COVID-19) entry by disrupting interaction between viral $\mathrm{S}$ - protein receptor binding domain and host ACE2 receptor. 
Virol. J. [Epub ahead of print]. Doi/;10.21203/RS-17806/V1.

Bhimanagouda S patil, G.K.J. Kotamballi $\mathrm{N}$ Chidambara Murthy., Beyond vitamin C: the diverse, complex health - promoting properties of citrus fruit. Citrus Research and Technology. 2017. 38 (1: p. 108-121.

CUBA (2014). Guiapara la prescripction de productos Naturales (La Habana: Ministerio de La Salud/Editorial Ciencias Medicas).

Francesco Megneguzzo, R.C., Federica Zabini, Mario Pagliaro., Acclerated production of hesperidin-rich citrus pectin pectin from waste citrus peel for prevention and therapy of COVID-19. Preprints. 020:p. 1-5.

Ghoke S.S., Sood, R., Kumar N., Pateriya, A.K., Bhatia, S., Mishra, A., et al., (2018). Evalution of antiviral activity of Occimum and Acacia Arabica leaves extracts against H9N2 virus using embryonated chiken egg model. BMC Complemetary Altern. Med. 18 (1), 174. Doi: 10.1186/s12906-018-2238-1. Heinrich, M., Appendino, G., Efferth, T., Fürst, R., Izzo, A. A., Kayser, O., et al. (2020). Best practice in research - Overcoming common challenges in phytopharmacological research. J. Ethnopharmacol. 246, 112230. doi: $10.1016 /$ j.jep.2019.112230

Ichsyani, M., Ridhanya, A., Risanti, M., Desti, H., Ceria, R., Putri, D. H., et al. (2017). Antiviral effects of Curcuma longa L. against dengue virus in vitro and in vivo. IOP Conf. Ser. Earth Environ. Sci. 101, 012005. doi: 10.1088/1755-1315/101/1/012005

Kim, H. J., Yoo, H. S., Kim, J. C., Park, C. S., Choi, M. S., Kim, M., et al. (2009). Antiviral effect of Curcuma longa Linn extract against hepatitis B virus replication. J. Ethnopharmacol. 124 (2), 189-196. doi:10.1016/j.jep.2009.04.046

Klimek-Szczykutowicz, M., Szopa, A., Ekiert, H. (2020). Citrus limon (Lemon) Phenomenon-
A Review of the Chemistry, Pharmacological Properties, Applications in the Modern Pharmaceutical, Food, and Cosmetics Industries, and Biotechnological $\begin{array}{llll}\text { Studies. } & \text { Plants } & 9, & 119 .\end{array}$ doi: $10.3390 /$ plants9010119

Mohmmad Nafees Iqbal and Suradkar SS, 2011. Ethnobotanical and Ethnomedicinal Study of some medicinal plants of Barshitakli Tahsil District Akola (MS) India. Bioscience Discovery, 2(2):236-239.

Muley JR and Sharma PP, 2013. Plants used in Tratment of Jaundice by Folklore of Ahmednagar district, Maharashtra, India. Science research Reporter, 3(2):216-222.

Munasir Z. (2000). Benefits of giving phyllanthus niruri extract as an immunostimuulator in infection disease of children. (On line). (cited 12/1/07);(3 pages).

Nag K and Zia-ul-Hasan, 2013. Study of some rare medicinal wild herbs from gardens of Bhopal city, Madhya Pradesh (India), Int. J. Parm. \& Life Sci., 3:2437-2439.

Naik V.N., 1998. Flora of Marathwada Voi-I \& II Amrut Publication, Aurangabad (M.S.) India.

Naik VN, 1998. Marathwadyatil samanya Vanaushadhi, Amrut Publications, Aurangabad (M. S.) India.

Nety, S., Koley, K. M., Choudhary, M., Chourasia, D., and Kumar, V. (2017). Comparative study of immunomodulatory effect of Tinospora cordifolia stem and Azadirachta indica leaf extract in broiler chicks. Vet. Pract. 18 (2), 286-288.

Nivetha, R., Bhuvaragavan, S., and Janarthanan, S. (2020). Inhibition of multiple SARS-CoV-2 proteins by an antiviral biomolecule, seselin from Aegle marmelos deciphered using molecular 
docking analysis. Res. Square [Epub ahead of print]. doi:10.21203/rs.3.rs-31134/v1

Pandey MM, Rastogi S, Rawat AK. 2013. Indian traditional ayurvedic system of medicine and nutritional supplementation. EvidenceBased Complementary and Alternative Medicine. 2013 Jan 1; 2013.

Pandu Hariyono Christine Patramurti Damiana S. Candrasari Maywan Hariono, (2021)An integrated virtual screening of compounds from Carica papaya leaves against multiple protein targets of SARS-Coronavirus-2

Patel, P., and Asdaq, S. M. B. (2010). Immunomodulatory activity of methanolic fruit extract of Aegle marmelos in experimental animals. Saudi Pharm. J. 18 (3), 161-165. doi:10.1016/j.jsps.2010.05.006

Rasool, A., Khan, M. U. R., Ali, M. A., Anjum, A. A., Ahmed, I., Aslam, A., et al. (2017). AntiAvian influenza virus H9N2 activity of aqueous extracts of Zingibero fficinalis (Ginger) and Allium sativum (Garlic) in chick embryos. Pak. J. Pharm. Sci. 30 (4), 13411344.

Rasool, M., and Varalakshmi, P. (2006). Immunomodulatory role of Withania somnifera root powder on experimental induced inflammation: an in vivo and in vitro study. Vasc. Pharmacol. 44 (6), 406410. doi:10.1016/j.vph.2006.01.015
Sampath Kumar, K. P., Bhowmik, D., Tiwari, P., and Kharel, R. (2010). Indian traditional herbs Adhatoda vasica and its Medicinal application. J. Chem. Pharm. Res. 2 (1), 240-245.

Sharma, V., Kaushik, S., Pandit, P., Dhull, D., Yadav, J. P., and Kaushik, S. (2019). Green synthesis of silver nanoparticles from medicinal plants and evaluation of their antivirolpotential against chikungunya virus. Appl. Microbiol. Biotechnol. 103 (2), 881-891. doi:10.1007/s00253-018-9488-1

Trivedi KP, 2003-2008. Vanaushadhi Visheshank Part 1-6, Shri Jwala Ayurved Bhavan Aligadh (U.P.) India.

Wisdom of tribals of Aurangabad district (M.S.), India. Indian J. of Natural Products and Resources, 2(1):102-109.

Xiang, Y., Pei, Y., Qu, C., Lai, Z., Ren, Z., Yang, K., et al. (2011). In vitro anti-herpes simplexvirusactivity of $1,2,4$, 6-tetra-Ogalloyl- $\beta$-D-glucose from Phyllanthus emblica L. (Euphorbiaceae). Phyther. Res 25 (7), 975-982. doi:10.1002/ptr.3368.

Ye, X. (2017). Phytochemicals in Citrus: Applications in Functional Foods (Boca Ratón: CRC Press). 


\begin{tabular}{|c|c|c|c|c|}
\hline $\begin{array}{l}\text { Sr. } \\
\text { No }\end{array}$ & Scientific name & Local Name & Family & Application against Covid-19 \\
\hline 1 & Tinospora cordifolia & Gulvel & Menispermaceae & $\begin{array}{l}\text { Aqueous extract leave and stem, early } \\
\text { morning }\end{array}$ \\
\hline 2 & Curcuma longa & Halad & Zingiberaceae & $\begin{array}{l}\text { Aqueous water extract rhizome and leaf } \\
\text { morning and sleeping time }\end{array}$ \\
\hline 3 & Ocimum sanctum & Tulas & Lamiacae & $\begin{array}{l}\text { Aqueous or hydroalcolic leaf extract } \\
\text { early morning }\end{array}$ \\
\hline 4 & Withania somnifera & Ashvagandha & Solanaceae & Aqueous root extract \\
\hline 5 & Zingiber officinal & Ginger & Zingiberaceae & $\begin{array}{l}\text { Aqueous rhizome extract and black tea, } \\
\text { daily } 2 \text { to } 3 \text { time }\end{array}$ \\
\hline 6 & Agele marmelos & Bael & Rutaceae & $\begin{array}{l}\text { Aqueous and alcoholic extract leave, } \\
\text { stem, fruit, and seed, two time }\end{array}$ \\
\hline 7 & Adathoda vasica & Adulasa & Acanthaceae & $\begin{array}{l}\text { Aqueous and ethanolic leaf extract } \\
\text { three time }\end{array}$ \\
\hline 8 & Citrus limon & Linboni & Rutaceae & $\begin{array}{l}\text { Leave extract and fruit juice daily three } \\
\text { time or two drop fruit juice through } \\
\text { nose two time }\end{array}$ \\
\hline 9 & Cocculus hirstus & Vasanvel & Menispermaceae & $\begin{array}{l}\text { Aqueous leave extract early morning } \\
\text { and afternoon }\end{array}$ \\
\hline 10 & Azadirachta indica & Neem & Meliceae & $\begin{array}{l}\text { Aqueous leaf, young stem extract daily } \\
2 \text { to } 3 \text { time }\end{array}$ \\
\hline 11 & Citrus sinensis & Orange & Rutaceae & $\begin{array}{l}\text { Leaf extract and fruit juice daily two } \\
\text { time }\end{array}$ \\
\hline 12 & Citrus limetta & Sweet orange & Rutaceae & $\begin{array}{l}\text { Leaf extract and fruit juice daily two } \\
\text { time }\end{array}$ \\
\hline 13 & Cymbopogon citrates & Lemon Grass & Poaceae & Leaf extract with tea 2 to 3 time daily \\
\hline 14 & Hyptis suaveolens & Rantulas & Laminaceae & Leaf extract early morning \\
\hline 15 & Aloe vera & Korpad & Asphodeloideae & Jelly leaf extract two time \\
\hline 16 & Eclipta alba & Flase daisy & Asteraceae & Aqueous leaf and prostrate extract \\
\hline 17 & Carica papaya & Papai & Caricaceae & Leaf extract with water early morning \\
\hline 18. & Phyllanthus nuri & Bhumiavla & Phyllanthaceae & Plant extract with warm water \\
\hline 19 & Boerhavia diffusa & Punarnava & Nyctaginaceae & Aqueous root extract \\
\hline 20 & Emblica offiinallis & Avla & Phyllanthaceae & Leaf extract and fruit juice \\
\hline 21 & Allium sativum & Garlic & Amaryllidaceae & Bulb and leaf extract with water \\
\hline
\end{tabular}

